\title{
Nucleolar organiser activity in Lolium and Festuca. 1. Lolium multiflorum, Festuca arundinacea and Lolium-Festuca Hybrids
}

\author{
Valdemar Carnide*, \\ Juan Orellanat and \\ Manuel A. M. Do Valle Ribeiroł
}

\author{
* Divisão de Genética e Melhoramento de Plantas, \\ Instituto Universitário de Traś-os-Montes e Alto \\ Douro, Vila Real, Portugal, \\ † Departamento de Genética, Facultad de Biologia, \\ Universidad Complutense, Madrid, Spain, \\ $\ddagger$ An Foras Taluntais, Oak Park Research Centre, \\ Plant Breeding Department, Carlow, Ireland.
}

Lolium multiflorum, Festuca arundinacea and $\boldsymbol{L}$. multiflorum-F. arundinacea hybrids were analysed by phase contrast, C-banding and silver-staining methods. Although the number of secondary constrictions detected by phase contrast was always six in $L$. multiflorum, it was very variable in $F$. arundinacea (4-12) and Lolium-Festuca hybrids (3-7); in these cases most of the constrictions appeared as euchromatic or c-hetero chromatic material when the $C$-banding technique was applied. By contrast the number of Ag-NORs was virtually constant in all plant varieties: six interstitial in $L$. multiflorum, two interstitial and two telomeric in $F$. arundinacea and three interstitial in the hybrids. These results indicate that not all the secondary constrictions detected by phase contrast are in fact nucleolar organiser regions. In addition a suppression of the nucleolar organisers of $F$. arundinacea by those of $L$. multiflorum was detected in the hybrids analysed.

\section{INTRODUCTION}

The evolutionary relationships of species have been studied with reference to their karyotypic similarities and differences, with special attention being given to the number and position of secondary constrictions (see Swanson, 1958).

Normally the karyotypic characteristics are virtually constant among cultivars within a given species (Chennaveeraiah, 1960). However, a wide variation in the number of secondary constrictions has been observed between cultivars when this analysis has been applied to $F$. arundinacea cultivars (Malik and Thomas, 1966). The nature of such unusual variation has not been analysed yet, probably due to the absence of accurate techniques.

It has been generally accepted that secondary constrictions are the sites of $18 \mathrm{~S}$ and $28 \mathrm{~S}$ ribosomal RNA genes. This has been confirmed by in situ hybridisation with labelled rRNA (see Howell, 1982 for a review). Although the correspondence between the chromosomal sites that bind the radioactive rRNA and the sites of the secondary con- strictions is very close, the correlation is not always perfect in some species because only the active nucleolar organiser regions (NORs) can produce secondary constrictions, whereas labelled rRNA can hybridise either with active or inactive NORs (see Lacadena et al., 1984).

Nucleolar organiser regions can be also detected by using silver staining methods, but in this case only the NORs which were functionally active during the preceeding interphase are detectable (Good pasture and Bloom, 1975; Tantravahi et al., 1976; Howell, 1977; Schwarzacher et al., 1978; Lacadena et al., 1984).

The aim of the present study is to analyse the nature of the variation in the number of secondary constrictions in Festuca arundinacea and LoliumFestuca hybrid plants.

\section{MATERIAL AND METHODS}

Three commercial cultivars of Festuca arundinacea, one of Lolium multiflorum and two Lolium multiflorum-Festuca arundinacea hybrids were analysed. 
Seeds were germinated on wet filter paper in Petri dishes at $20^{\circ} \mathrm{C}$. When primary roots were $1 \mathrm{~cm}$ long they were excised and immersed in tap water at $0^{\circ} \mathrm{C}$ for 16 hours to shorten the chromosomes. Subsequently the tips were fixed in acetic ethanol $1: 3$ and stored at $0^{\circ} \mathrm{C}$ for several months.

The fixed material was crushed and the metaphase cells were observed by phase contrast and stained following the Giemsa C-banding technique or the silver staining technique according to Giraldez et al., (1979) and Lacadena et al., (1984) respectively.

\section{RESULTS}

As has been reported on several occasions Lolium multiflorum shows three chromosome pairs with secondary constrictions located near centromeric regions (Malik and Thomas, 1966; Thomas, 1981). The nucleolar organiser nature of such constrictions is demonstrated by the persistent presence of Ag-stained material in all of them and by good correspondence between the number of secondary constrictions at somatic metaphase and the maximum number of nucleoli in interphase nuclei (table 1) (see fig. 1).

In the present study we analysed the metaphase chromosomes of three hexaploid cultivars of $F$. arundinacea by phase contrast, C-banding and Ag-staining methods.

The number of secondary constrictions detected by phase contrast was very variable both among cells within the same plant and among plants of the same cultivar: 3 to 10 in $\mathrm{cv}$. S 170 (this cultivar was also studied by Malik and Thomas, 1966), 4 to 11 in $\mathrm{cv}$. Festorina and 4 to 12 in $\mathrm{cv}$. Ondine. A high degree of heterogeneity was also observed in the size of such constrictions found in metacentric and submetacentric chromosomes (see fig. 2). Their location seems to be mostly at interstitial sites and in a few cases at the telomeres (fig. 2).

It is well known that the Giemsa C-banding technique does not stain the chromosomal material of nucleolar organiser regions (see Linde-Laursen, 1984). For this reason the phase contrast and Cbanding techniques were combined in order to determine the nucleolar organiser nature of the secondary constrictions. So, C-banding was applied to the same cells which had previously been analysed by phase contrast. Festuca arundinacea shows a C-banding pattern characterised by the presence of $\mathrm{C}$-hereto chromatic bands in centromeric, pericentromeric, interstitial and telomeric regions. There is also variation between plants and cultivars (Carnide, in preparation).

Many constrictions detected by phase contrast were not observable when C-banding was applied (fig. 2). The distal constrictions appeared as Cheterochromatic blocks in all cases (fig. $2(m-p)$ ), whereas interstitial ones became apparent as euchromatic (fig. 2(c-r)) or C-heterochromatic (fig. 2(i-1)) material. Only one or two chromosomes maintained their interstitial constrictions after the C-banding procedure (fig. 2(s-t)). Telomeric constrictions were also maintained in a very few cases. However, it is worth mentioning that not all Cbands detected appeared as constrictions when phase contrast was used (fig. 2(q-r)).

These results indicate that most of the secondary constrictions of hexaploid F. arundinacea are not actual nucleolar organiser regions.

Table 1 Ag-NORs and nucleoli observed in somatic metaphase and interphase cells, respectively, in Lolium multiflorum, Festuca arundinacea and Lolium multiflorum-Festuca arundinacea hybrids

\begin{tabular}{|c|c|c|c|c|c|c|c|c|c|c|c|c|c|}
\hline \multirow[b]{2}{*}{ Material } & \multirow{2}{*}{$\begin{array}{l}\text { No. } \\
\text { plants }\end{array}$} & \multicolumn{6}{|c|}{ Ag-NORs/Metaphase } & \multicolumn{6}{|c|}{ No. of nucleoli at interphase* } \\
\hline & & 2 & 3 & 4 & 5 & 6 & 1 & 2 & 3 & 4 & 5 & 6 & Total \\
\hline \multicolumn{14}{|l|}{ L. multiflorum } \\
\hline cv. Lemtal & 4 & & & 1 & 3 & 3 & 473 & 282 & 54 & 10 & 2 & 1 & 822 \\
\hline \multicolumn{14}{|c|}{ F. arundinacea } \\
\hline cv. Ondine & 3 & - & 4 & 22 & - & - & 147 & 470 & 437 & 149 & 一 & - & 1203 \\
\hline \multicolumn{14}{|c|}{ L. multiflorum $-F$. arundinacea } \\
\hline K5 & 3 & 3 & 41 & - & - & - & 574 & 471 & 60 & 一 & 一 & - & 1105 \\
\hline K7 & 3 & - & 51 & - & - & 一 & 440 & 508 & 90 & - & - & 一 & 1038 \\
\hline
\end{tabular}

* Contingency tests of the distribution of the number of nucleoli observed in different individuals of each plant type were not significant and, consequently, the data were pooled. 


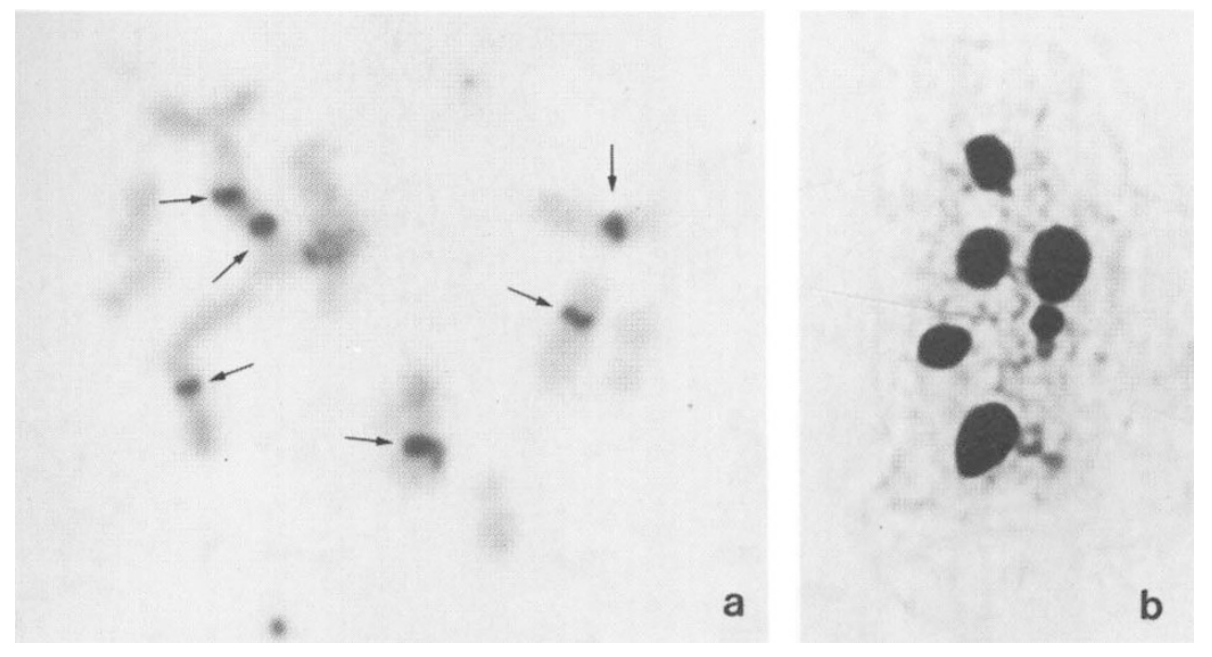

Figure 1 Silver staining in L. multiflorum. (a) Somatic metaphase celi with six Ag-NORs. (b) Interphase nucleus with six nucleoli. Arrows indicate $\mathrm{Ag}-\mathrm{NORs}$.

In addition nucleolar activity was analysed by using the silver-staining method which allows us to detect the number of active nucleolar organiser regions (NORs) at somatic metaphase and the number of nucleoli at interphase. For all cultivars analysed, only four chromosomes with active NORs (two interstitial and two telomeric) were observed at metaphase (fig. 3(a)) (table 1).

Now, if the silver-staining method reveals the active NORs, the maximum number of nucleoli per cell at interphase should correspond to the number of Ag-NORs at interphase (see Lacadena et al., 1984). In all cases the results obtained from interphase cells were in agreement with those obtained from metaphase cells (fig. 3) (table 1).

Although the number of active Ag-NORs was virtually constant in all cells, plants and cultivars, the size of the NORs was different in many cases. Table 2 shows the frequency of cells NORs of the same or a different size.

The number of secondary constrictions was also very variable in $L$. multiflorum $-F$. arundinacea hybrid plants: three to seven in $\mathrm{K} 5$ and three to six in $\mathrm{K} 7$, and similar results to those observed in Festuca were observed after C-banding.

In accordance with the results reported above it was expected that five Ag-NORs would be found in Lolium-Festuca hybrid plants (three from Lolium and two from Festuca). However, in all the hybrids analysed only three interstitial Ag-NORs and a maximum of three nucleoli per nucleus were observed (fig. 4) (Table 1). The location of these NORs appeared to be very similar to that observed in Lolium multiflorum (see fig. 1 and 4). As in Festuca variation in size of the NORs was also observed (table 2).

\section{DISCUSSION}

Silver preferentially reacts with acid proteins which bind the newly synthesised rRNA and in this way only the NOR's which were active during the preceeding interphase are specifically detectable by silver-staining (Goodpasture and Bloom, 1975: Howell, 1977; Schmid et al., 1977). However the results must be treated with caution since NORs are not detected by silver-staining either when the level of activity the rRNA genes is low (Schmiady et al., 1979) or when the number of

Table 2 Frequency of cell-types according to whether the size of Ag-NORs was the same or different

\begin{tabular}{lllll}
\hline & \multicolumn{2}{l}{$\begin{array}{l}\text { Telomeric } \\
\text { Ag-NORs }\end{array}$} & \multicolumn{2}{l}{$\begin{array}{l}\text { Interstitial } \\
\text { Ag-NORs }\end{array}$} \\
\cline { 2 - 5 } & $\begin{array}{l}\text { Same } \\
\text { size }\end{array}$ & $\begin{array}{l}\text { Different } \\
\text { size }\end{array}$ & $\begin{array}{l}\text { Same } \\
\text { size }\end{array}$ & $\begin{array}{l}\text { Different } \\
\text { size }\end{array}$ \\
\hline $\begin{array}{l}\text { F. arundinacea } \\
\text { cv. S 170 }\end{array}$ & 22 & 5 & & \\
cv. Festorina & 19 & 7 & 18 & 8 \\
cv. Ondine & 21 & 4 & 14 & 11 \\
L. multiflorum-F. & arundinacea & & \\
K5 & - & - & 4 & 40 \\
K7 & - & - & 3 & 48 \\
\hline
\end{tabular}




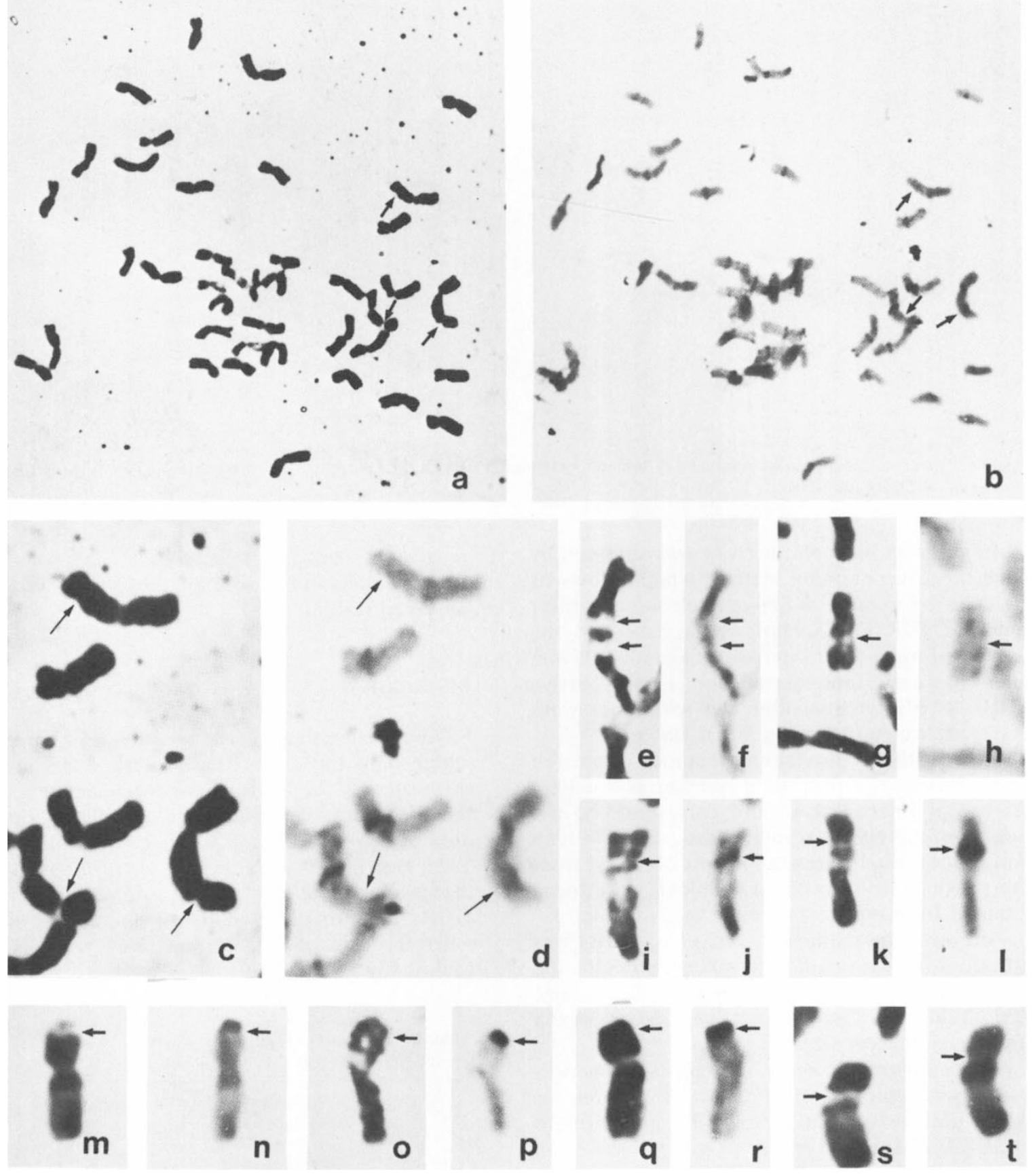

Figure 2 Phase contrast and C-banding in F. arundinacea. (a) Phase contrast of a somatic metaphase cell of cv. S170. (b) The same cell after $\mathrm{C}$-banding. (c-t) Phase contrast and $\mathrm{C}$-banding of metaphase chromosomes and chromosome groups. Arrows indicate secondary constrictions and these constrictions after C-banding. 

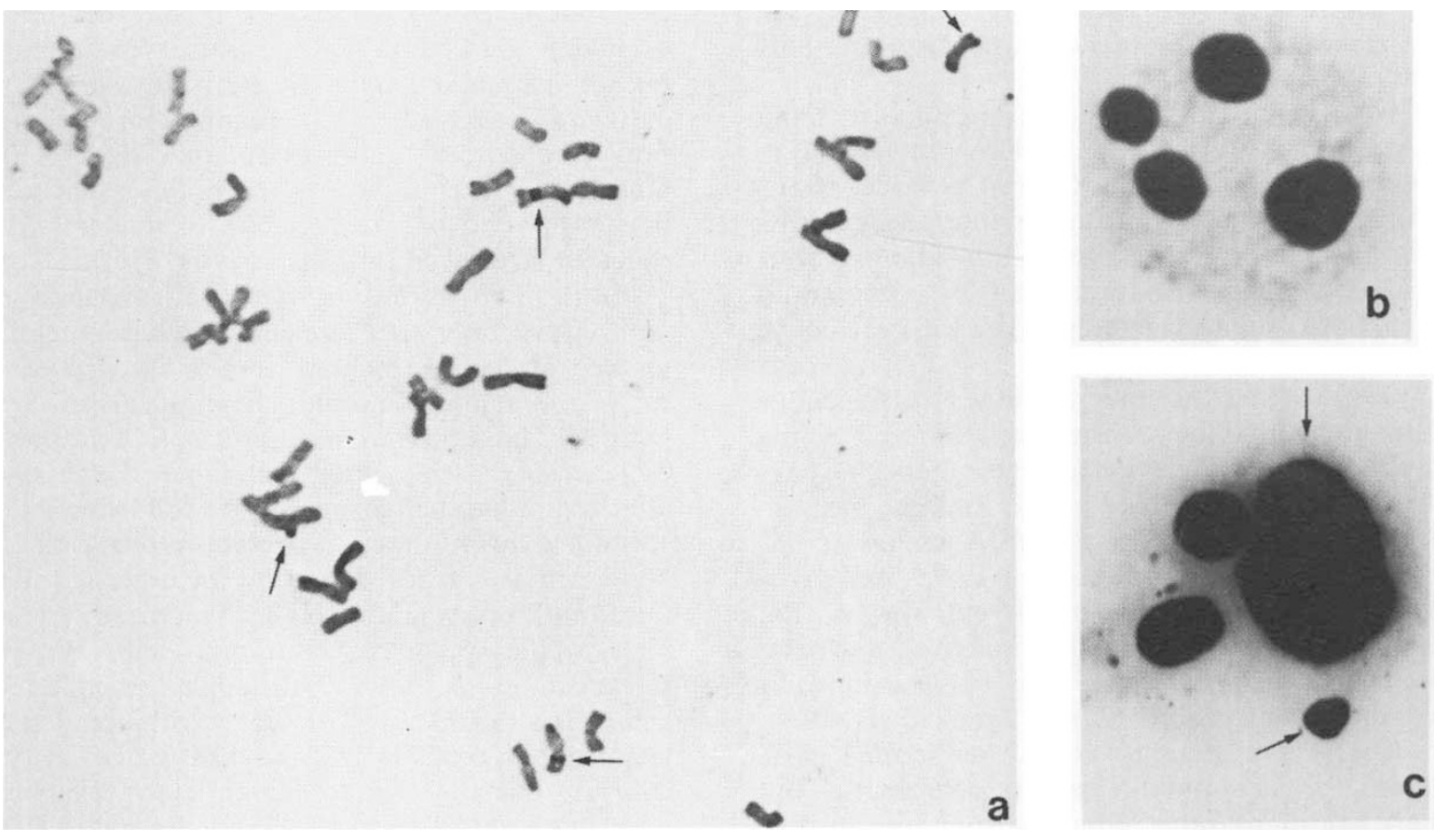

Figure 3 Silver staining in F. arundinacea. (a) Somatic metaphase cell of cv. Festorina. Arrows indicate Ag-NORs. (b-c) Interphase cells. Arrows indicate nucleoli of different size.
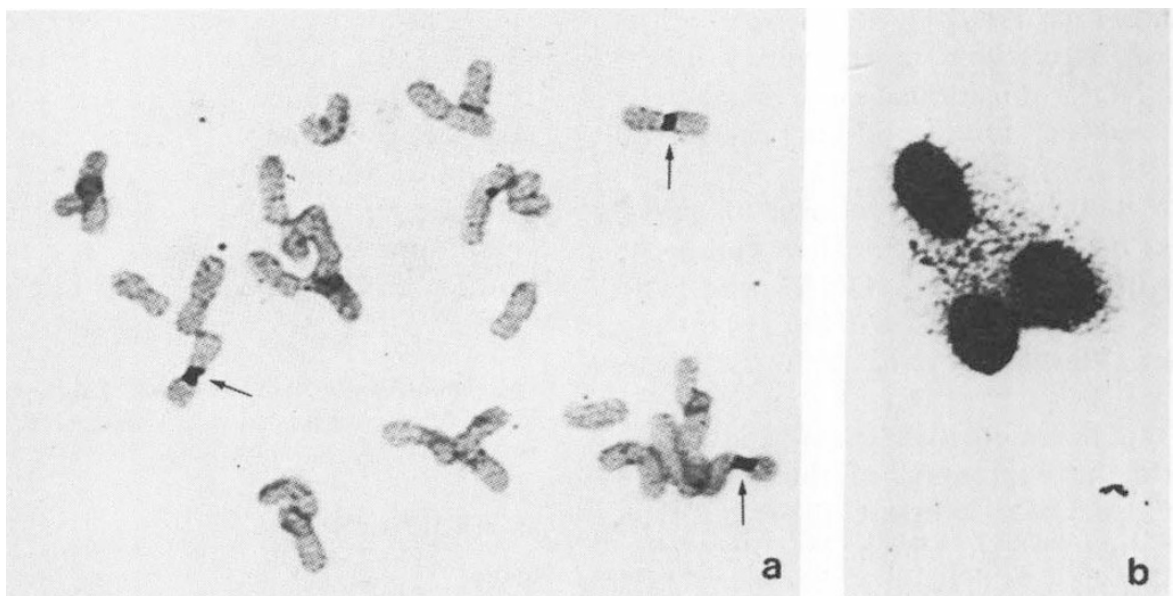

Figure 4 Silver staining in Lolium-Festuca hybrids plants. (a) Somatic metaphase with three Ag-NORs in the hybrids K7. (b) Interphase nucleus with three nucleoli. 
rRNA gene copies is low (Sato et al., 1980; Cermeño et al., 1984). This may be responsible for the appearance of telomeric constrictions in a very few cases.

However, minute NORs not detectable by silver at metaphase always from nucleoli, and therefore the number of active NORs must be equal to the maximum number of nucleoli in interphase nuclei. For this reason we can conclude that the four $\mathrm{Ag}-\mathrm{NORs}$ (two interstitial and two telomeric) detected at somatic metaphase are the only active ones in Festuca arundinacea.

Besides the nucleolar organiser constrictions there are many other constrictions whose meaning is unknown. A moderate to high number of constrictions not detectable by silver staining has also been observed in other genera, such as Secale, Hordeum, Triticum, Avena and Agropyron (Orellana, unpublished). In any case they do not seem to correspond with inactive nucleolar organiser regions because they show a negative response to hybridisation with labelled rRNA.

These constrictions could be stained with Giemsa as euchromatin or heterochromatin, but there are many other c-heterochromatin-positive sites that are not shown up as constrictions by phase contrast. This indicates that there is a great degree of heterogeneity within both euchromatic and heterochromatic segments. This type of heterogeneity has been described on many occasions (John and King, 1977; Gosalvez and López-Fernandez, 1981; Rocchi, 1982; Camacho et al., 1984) and its molecular characterisation has been recently initiated by the development of differential fluorochrome techniques (Deumling et al., 1982; John et al., 1985).

In addition, karyotypic heterogeneity in the size of the Ag-NORs at metaphase and the nucleoli at interphase was also found both in Festuca and Lolium-Festuca hybrids (see table 2).

Variations in the number and size of silverstained NORs have been explained as being due to differences in the number of rDNA copies, and they seem to be a general feature in both plant and animal species (Warburton et al., 1976; Ditties et al., 1975).

It is clear that the intensity of the silver-staining correlates with the expression of the secondary constrictions (see Linde-Laursen, 1984) but it is also true that the extent to which secondary constrictions are expressed varies during the cell cycle and often from cell to cell and from tissue to tissue (Hsu et al., 1967). Moreover, the pretreatment to shorten the chromosomes could be very significant (Orellana, unpublished). In spite of this, the differences between plants and between populations found in $F$. arundinacea might indicate the existence of a certain polymorphism for the number of nucleolar organiser gene clusters in the cultivars analysed. The assumption of such polymorphism is quite reasonable due to the allogamous reproductive system of this species and it is supported by the presence of nucleoli with different sizes at interphase (see fig. 3(c)).

In the Lolium-Festuca hybrid plants analysed in this work, only three nucleolar organiser regions, located at pericentrosites, were active, therefore the phenomenon of amphiplasty appears in these hybrids. The term amphiplasty was first proposed by Navashin $(1928 ; 1934)$ to designate the changes affecting individual chromosomes following interspecific hybridisation. Complete suppression of NOR activity of one parent by the other is called total amphiplasty, and it has been reported in many interspecific plant and animal hybrids (see Lacadena et al., 1984). Although the mode of action is still unknown, it seems to be related to genome interactions which take place in the hybrids, but the effect is completely reversible when the interaction genomes are separated from each other (Rieger et al., 1979).

In our case, the NORs activity of Festuca arundinacea was totally suppressed by the presence of Lolium chromosomes in a common nucleus.

Lolium species (particularly $L$. perene and $L$. multiflorum) have been put forward as one of the diploid donors in the evolution of hexaploid $F$. arundinacea (Carnahan and Hill, 1961). However, our results make it difficult to see how that could be so, since in that case we would expect at least three chromosome pairs with pericentromeric AgNORs, due to the existence of total amphiplasty, but not two pairs, one pericentromeric and other telomeric. Probably further analysis combining meiotic and mitotic data obtained by Ag-staining, C-banding and differential fluorescence techniques could provide valuable new information about the genomic origin of polyploid Festuca.

Acknowledgment This study was kindly supported by a grant from the Fundação Calouste Gulbenkian, Lisboa, Portugal.

\section{REFERENCES}

CAMACHO, J. P. M., VISERAS, E., NAVAS, J. and CABRERO, J. 1984. C-heterochromatin content of supernumerary chromosome segments of grasshoppers: detection of an euchromatic extra segment. Heredity, 53, 167-175.

CARNAHAN, N. L. AND HILL, H. D. 1961. Cytology and Genetics of forage grasses. Bot. Rev., 27, 1-162. 
CERMEÑo, M. C., ORELlanA, J., SANTOS, J. L. AND LACADENA, J. R. 1984. Nucleolar organizer activity in wheat, rye and derivatives analysed by silver-staining procedure. Chromosoma, 89, 370-376.

CHENNAVEERAIAH, M. S. 1960. Karyomorphologic and cytotaxonomic studies in Aegilops. Acta Hoti. Gotoburgensis, 23, 85-178.

DEUMLING, B. AND GREILHUBER, J. 1982. Characterization of heterochromatin in different species of the Scilla siberica group (Liliaceae) by in situ hybridisation of satellite DNA and fluorochrome banding. Chromosoma, 84, 535-555.

DITTIES, H., KRONE, W., BROSS, K., SCHMID, M. AND VOGEL, w. 1975. Biochemical and cytogenetic studies on the nucleolus organizing regions (NOR) of man. Hum. Genet., 26, 47-59.

GiRAldez, R., CERMEÑo, M. C. AND ORELlanA, J. 1979. Comparison of $C$-banding pattern in the chromosomes of inbred lines and open pollinated varieties of rye. $Z$. Pflanzenzücht., 83, 40-48.

GOODPASTURE, C. AND BLOOM, S. E. 1975. Visualization of nucleolar organizer regions in mammalian chromosomes using silver staining. Chromosoma, 53, 37-50.

GOSALVEZ, J. AND LOPEZ-FERNANDEZ, C. 1981. Extra heterochromatin in natural populations of Gomphocerus sibiricus (Orthoptera: Acrididae) Genetica, 56, 197-204.

HOWELL, W. M. 1977. Visualization of ribosomal gene activity: silver stains proteins associated with rRNA transcribed from oocyte chromosomes. Chromosoma, 62, 361-367.

HOWELL, W. M. 1982. Selective staining of nucleolus organizer regions (NORs). Cell. Nucleus, 11, 89-142.

HSU, T. C., BRINKLEY, B. R. AND ABRIGHI, F. E. 1967. The structure and behaviour of the nucleolus organizers in mammalian cells. Chromosoma, 23, 137-153.

JOHN, B. AND KING, M. 1977. Heterochromatin variation in Cryptobothrus chrysophorus. II, Patterns of C-banding, Chromosoma, 65, 59-79.

JOHN, B., KING, M., SCHWEIZER, D. AND MENDELAK, M. 1985. Equilocality of heterochromatin distribution and heterochromatin heterogeneity in acridic grasshoppers. Chromosoma, 91, 185-200.

LACADENA, J. R., CERMEÑo, M. C., ORELlANA, J. AND SANTOS, J. L. 1984. Evidence for wheat-rye nucleolar competition (amphyplasty) in triticale by silver-staining procedure. Theor. Appl. Genet., 67, 207-313.
LINDE-LAURSEN, I. 1984. Nucleolus organizer polymorphism in barley. Hordeum vulgare L. Hereditas, 100, 33-43.

MALICK, C. P. AND THOMAS, P. T. 1966. Karyotypic studies in some Lolium and Festuca species. Caryologia, 19, 167-196.

NAVASHIN, M. S. 1928. Amphiplastie-cine neue Karyologis che Erscheinung Proc. Int. Conf. Genet., 5, 1148-1152.

NAVASHIN, M. S. 1934. Chromosome alterations caused by hybridisation and their bearing upon certain general genetic problems. Cytologia, 51, 169-203.

RIEGER, R., NICOLOFF, H. AND ANASTASSOVA-KRISTEVA, M. 1979. "Nucleolar dominance" in interspecific hybrids and translocation lines-a review. Biol. Z Zbl., 48, 385-398.

ROOCHI, A. 1982. On the heterogeneity of heterochromation. Caryologia, 35, 169-189.

SATO, S., HIZUME, M. AND KAWAMURA, S. 1980. Relationship between secondary constrictions and nucleolar organizing regions in Allium sativa chromosomes. Protoplasma, 105, $77-85$.

SCHMIADY, H., MUNKE, M. AND SPERLING, K. 1979. Agstaining of nucleolus organizer regions on human condensed chromosomes from cells with different ribosomal RNA gene activity. Expl. Cell. Res., 121, 425-428.

SCHMID, M., HOFGÄRTNER, F. J., ZENSES, M. T. AND ENGEL, W. 1977. Evidence for postmeiotic expression of ribosomal RNA genes during male gametogenesis. Hum. Genet., 38, 279-284

SCHWARZACHER, H. G., MIKELSAAR, A. V. AND SCHNEDL, W. 1978. The nature of the Ag-staining of nucleolus organizer regions. Electron and light-microscopy studies on human cells in interphase, mitosis and meiosis. Cytogenet. Cell Genet., 20, 24-39.

SWANSON, C. P. 1958. Cytology and cytogenetics. Macmillan \& Co. Ltd., London.

TANTRAVAHI, R., MILlER, D. A., DEV, V. G. AND MILlER, O J. 1976. Detection of nucleolus organizer regions in chromosomes of human, chimpanzee, gorilla, orangutan and gibbon. Chromosoma, 56, 15-27.

THOMAS, H. M. 1981. The Giemsa C-band Karyotypes of six Lolium species. Heredity, 46, 263-627.

WARBOUTON, D., ATWOOD, K. C. AND HENDERSON, A. S. 1976. Variation in the number of genes rDNA among human acrocentric chromosomes. Correlation with frequency of satellite association. Cytogenet. Cell Genet, 17, 221-230. 